\title{
Overcome the Impairment of NK Cells for Icon and Antibody Immunotherapy of Cancer
}

\author{
Zhiwei Hu \\ Department of Surgery, The Ohio State University College of Medicine, Columbus, USA \\ Email: zhiwei.hu@osumc.edu
}

Received September 14, 2012; revised October 20, 2012; accepted November 26, 2012

\begin{abstract}
Natural killer (NK) cells play an important role in innate immunity and in mediating antibody and Icon (an antibody-like factor VII/IgG1 Fc immunoconjugate, which, to our best knowledge, was the first therapeutic agent for dual targeting of both the tumor cells and tumor angiogenic endothelial cells) for cancer immunotherapy. However, a common yet often neglected observation and challenge in antibody immunotherapy is that NK cells are often impaired in cancer patients. Here we hypothesize that the impairment of NK cells significantly contributes to host resistance to antibody immunotherapy for cancer. In order for antibody and Icon to achieve their optimal therapeutic efficacy, we briefly reviewed the current strategies to enhance NK activity, including infusion of cytokines, vaccines or NK cells, and the use of dietary supplements. Moreover, from our point of view we identified some remaining challenges and propose to combine these NK-enhancing strategies with Icon or antibody to overcome NK impairment and ultimately to optimize the efficacy of Icon and antibody immunotherapy for cancer.
\end{abstract}

Keywords: Natural Killer Cells; Antibody; Cancer Immunotherapy; Icon; Dietary Supplements

\section{Introduction}

Natural killer (NK) cells are a class of lymphocytes distinct from T- and B-cells and play an important role in the innate immune system for direct killing of virusinfected cells and cancer cells as well as in antibodymediated killing in antibody immunotherapy of cancer $[1,2]$. NK cells are large granular lymphocytes lacking of CD3 and T cell receptors and compose about $10 \%-20 \%$ of peripheral blood lymphocytes in healthy individuals $[1,3,4]$. They commonly express certain cell surface markers such as CD16 and CD56 in humans and NK1.1/NK-2.1 and CD49b in mice for identification and isolation of NK cells. CD56+ and CD3- can be used as distinct surface markers for identification of human NK cells, whereas CD16 is the receptor for the Fc portion of immunoglobulin gamma (IgG Fc) ( $\mathrm{Fc} \gamma \mathrm{RIII}$ receptors) to mediate antibody-dependent cell-mediated cytotoxicity (ADCC). In addition, NK cells can produce a variety of cytokines [5], e.g., interleukin-1 (IL-1), IL-2, IL-4, IL-12, IL-15, interferons (IFN), tumor necrotic factors (TNF- $\alpha$ and $\beta$ ), etc. These NK-producing cytokines have numerous widespread actions including direct anti-tumor effects and autochthonous NK regulation.

\section{Antibody and Icon Immunotherapy for Cancer}

In the past decades, effects have been focused on identi- fication of target antigens on one of two major tumor compartments, either tumor cells or tumor neovasculature, and subsequently several therapeutic chimeric or completely humanized antibodies have been developed against common growth factors or their receptors [6], such as epidermal growth factors HER-1 (Cetuximab), HER-2/neu (Trastuzumab), or angiogenic growth factors, such as vascular endothelial growth factor (VEGF) (Bevacizumab), for cancer immunotherapy.

We proposed that simultaneous targeting of both the tumor compartments, i.e., tumor cells and tumor neovasculature, could achieve better therapeutic effect than targeting of tumor cells or tumor neovasculature alone [7]. In this regard, we constructed in 1999 the first dual neovascular- and tumor cell-targeting antibody-like factor VII/IgG1 Fc immunoconjugate molecule [8], later called an Icon $[9,10]$ (Figure 1). The Icon is composed of two mature factor VII (fVII) polypeptides with a mutation of Lys341Ala (K341A) fused to the Fc domain of a human IgG1 antibody by recombinant DNA technology [8-11]. The reason for introducing Alanine mutation to Lysine 341 in fVII protein was to reduce its coagulation activity while its binding activity to TF retains [10]. The Icon molecule is designed to bind to tissue factor (TF), a common yet specific target molecule on tumor angiogenic endothelial cells (but not on normal resting vascular endothelial cells) and many types of cancer cells $[8,10,12]$, 


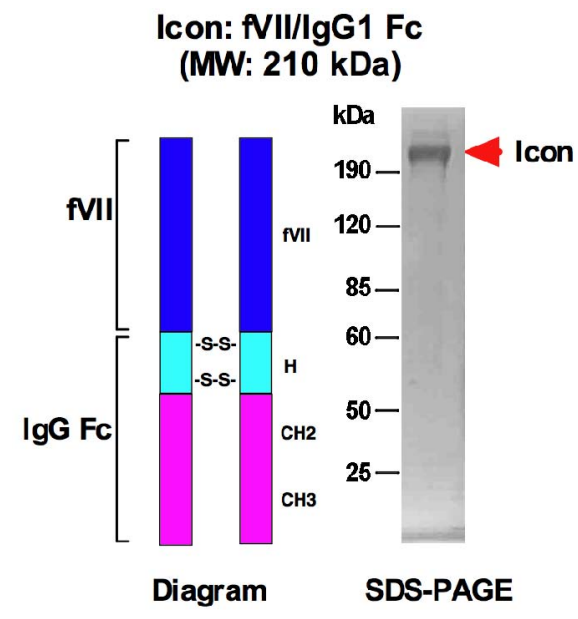

Figure 1. Diagram and molecular weight of the Icon (factor VII/IgG1 Fc) for cancer immunotherapy. fVII: factor VII with a K341A mutation; $\mathrm{H}, \mathrm{CH} 2$ and $\mathrm{CH} 3$ : hinge and constant regions of IgG1 Fc; -S-S-: disulfide bonds. MW: molecular weights; fVII: factor VII; kDa: kilodaltons.

with far higher affinity and specificity than can be achieved with an anti-TF antibody. We tested the efficacy and safety of Icon immunotherapy for cancer in several mouse models of primary and metastatic mouse and human cancer $[9,10,13]$, including melanoma $[8,9]$, prostate [10], breast [13], tongue [11] and endometrial [14] cancer. The results of these extensive tests demonstrated that the Icon immunotherapy eradicated primary and disseminated metastatic tumors without associated toxicity [8-11, 13,14]. In addition for cancer treatment, we and our collaborators also showed that Icon immunotherapy could eradicate choroidal neovasculature in mouse and pig models simulating the wet form of age-related macular degeneration [15,16], as either intravenous or intraocular injections with Icon protein or encoded in replicationincompetent adenoviral vector, and that Icon protein eradicated human endometriosis in a nude mouse model [17].

\section{Crucial Role of NK Cells in Icon and Antibody Immunotherapy of Cancer}

NK cells play two distinct roles in cancer immunotherapy, the first being to prevent tumor development by direct killing as innate immune cells and the other to mediate ADCC by antibody or Icon-guided specific killing after antibody or Icon immunotherapy is initiated [11]. We recently reported for the first time that NK cells are crucial for the efficacy of Icon immunotherapy for human cancer in preclinical mouse models [11]. Previous reports also showed that NK cells could mediate ADCC for other therapeutic antibodies including Trastuzumab (Herceptin) for breast cancer [18], Rituximab (Rituxan) for B-cell lymphoma [19], and Cetuximab for lung cancer
[20]. Thus NK cells play important, or even crucial, role in Icon and antibody immunotherapy for cancer.

\section{Impairment of NK Cells in Cancer Patients}

A major challenge, yet often neglected, in antibody immunotherapy is the impairment of NK cells in cancer patients, which could be responsible for host resistance to antibody immunotherapy. A few years after the discovery of NK cells [21-23], it was found that NK cells could be impaired, observed as lower level/decreased activity in peripheral blood lymphocytes (PBL), by tumors in animals and cancer patients [24]. In later years, more reports showed that the ADCC activity of NK cells was impaired in patients with cancer $[1,25,26]$, including head and neck [27,28], breast [29], gastric [30], esophageal [31,32], cervical [33] and urologic cancers [34] as well as leukemia [35-37] and myeloma [38]. In addition, NK activity could decline with age [39], which may contribute to and explain why higher incidence of cancer developed in elderly populations. With regard to the role of NK cells in Icon immunotherapy for cancer, we observed in a recent study [11] that Icon immunotherapy was able to completely eradicate human tongue tumor xenografts in the CB-17 strain of SCID mice that have functional and normal levels of NK cells [40], but not in the Beige strain of SCID mice that have defective NK cells $[41,42]$. Icon was also unable to completely eradicate human tongue tumor xenografts in some of the partially responded CB-17/SCID mice, in which NK cell percentages $(3.7 \% \pm 0.9 \%)$ of PBL were lower than the normal average (16\% of PBL) [11]. Since both SCID strains are deficient of T- and B-cells [40,41], we concluded that impairment of NK cells significantly contributed to host resistance to Icon or antibody immunotherapy for cancer [11].

Implication of resistance to antibody has also been observed in clinical trials. For example, there were $66 \%$ $88 \%$ of patients with metastatic breast cancer with resistance to single agent Her2-targeted trastuzumab immunotherapy even though the cancer cells overexpressed the Her2 antigen [43]. To find out the factors causing the resistance, Varchetta et al., analysed circulating mononuclear cells in 18 breast cancer patients after Her2 targeted-trastuzumab therapy and concluded that quantity and lytic efficiency of CD16+ NK cells are major factors for the effectiveness of trastuzumab immunotherapy [44]. The mechanism of impairment of NK cells by cancer cell remains to be investigated. Taken together, these findings suggest that impairment of NK level/activity contributes to resistance to Icon and other therapeutic antibodies that are currently under investigation in preclinical and clinical studies. 


\section{Current Strategies to Enhance NK Activity}

\subsection{The Use of NK-Stimulating Cytokines/Vaccines and Infusion of NK Cells}

Efforts are made to stimulate NK cells by one of at least two methods: infusion of NK-activating cytokines or vaccines (to activate the impaired endogenous NK cells) and infusion of autologous or allogeneic NK cells (to replace the impaired endogenous NK cells). Vaccines, usually derived from irradiated whole cancer cells, can stimulate immune cells and cytokines in broad range, whereas cytokines, with better-defined mechanism of action, can activate certain types of immune cells. The use of cytokines, including IL-2, IL-12, IL-15, IL-18, IL-21, interferons (IFNs), and other biological molecules such as $\mathrm{CpG}$ oligodeoxynucleotides to enhance NK activity have been well established in preclinical studies and clinical applications [45-53].

However, both methods currently have their limitations. With cancer cell vaccine, these whole-cell vaccines as single agent therapy did not show efficacy in several Phase III clinical trials [54]. With cytokines, they are limited because cytokines as protein molecules with short half-life have to be administered repeatedly in vivo and are therefore associated with significant toxicity at high dose $[55,56]$ or with uncertain efficacy at lower doses [57]. Infusions of autologous or allogeneic NK cells for cancer therapy have been shown feasible and well-tolerated in cancer patients [58-60]. Although it was safe, efficacy of clinical trials with infusion of autologous NK cells shows no effect [61]. Similarly, Dr. Rosenberg's group at the National Cancer Institute of NIH recently reported that adoptive transfer of autologous NK cells as single agent therapy could maintain high levels of circulating NK cells in patients but did not mediate tumor regression [62]. With allogeneic NK cells, the limitations are that other peripheral blood lymphocytes are always contaminated in the final NK products even under Good Manufacture Production (GMP) [63] and those NK cells from donors likely differ in killing activity from individual to individual [5].

\subsection{The Use of Dietary Supplements}

Thornthwaite et al. [23], recently summarized and reviewed anti-cancer effect of 16 dietary supplements, including Alpha Lipoic Acid, Arabinoxylin, Curcumin, Garlic, Genistein, Ginseng, Lentinan, Mistletoe, N-Acetylcysteine, Resveratrol, Selenium, Vitamin B, Vitamin C, Vitamin D3, Vitamin E and zinc. Evidence suggested that their anti-cancer effect was partly mediated by upregulating immune function [64,65], particularly NK activity, or even inhibiting cancer stem cells [66]. In addition, there are many other dietary components that are shown to have anti-cancer effect, including green tea and its extracts [67,68], grape and grape skin extracts [69], etc. Some of these dietary supplements have been tested in animal models of cancer $[65,70]$ and cancer patients [71-80]. However, caution should be taken since adverse effects have been observed in clinical trials of some dietary supplements [81-83]. To obtain consistent clinical effect, standardization for extraction procedures and GMP of clinic-tested dietary supplements remain to be developed/optimized [84].

\section{Remaining Challenges}

To overcome the limitations of current efforts on enhancing NK activity and to achieve an optimal therapeutic efficacy for cancer patients, we propose to synergistically combine antibody or Icon with these NK-stimulating strategies (the use of biologic agents, NK cells and/or dietary supplement) for cancer immunotherapy.

In order to evaluate NK activity/level among cancer patients with antibody and Icon immunotherapy, it would be ideal and helpful to use common NK lines as standard NK effector cells and common NK activity/level assays, which remain to be developed. Therefore, from our point of view we believe that other remaining challenges in antibody immunotherapy are as follows: 1) to develop immortalized NK cell lines with ability to mediate antibody ADCC function as standard NK cell line for comparing and determining cancer patient's NK activity; 2) to develop a more convenient method, ideally, to measure both the NK cell level (percent and/or actual number of NK cells in peripheral blood lymphocytes) and activity (function) for routine use in clinical laboratories.

Regarding immortalized NK lines, there are a few studies on generation of murine NK [85-89] and human NK [90] cell lines. Dr. Tian and coworkers recently summarized the NK cell lines in cancer immunotherapy [48]. However, it was unclear if those NK cell lines were able to mediate ADCC. Moreover, many of them are not publicly available, for example, from ATCC. To our best knowledge, the only two human NK lines available at ATCC are NK-92 (IL-2 dependent) and NK-92MI (IL-2 independent) $[91,92]$. But they were derived from a patient with lymphoma and do not express CD16, and therefore they cannot mediate ADCC.

Currently NK activity in ADCC has been mainly determined by the radioactive isotope Chromium-51 $\left({ }^{51} \mathrm{Cr}\right)$ release assay, in which target cells (e.g., cancer cells) are first dissociated and then labeled with ${ }^{51} \mathrm{Cr}$ sequentially followed by incubation with test antibody and then with PBL or isolated NK cells. To avoid the use of radio-isotope and dissociation of target cells, our group [11] and others [93] have used non-radioisotope assays, in which the target cancer cells are labeled in the wells of mcroas- 
say plates with fluorescent dyes (e.g., Calcein AM). To measure mouse NK level in PBL, we recently established a flow cytometry protocol using fluorescent dye-conjugated anti-mouse CD49b (clone DX5) [11]. Since CD49b is expressed by the majority of NK cells (and a small Tcell subpopulation) in most mouse strains [94], this flow cytometry procedure for mouse NK level could be broadly used in mouse studies. Similarly, a flow cytometry using anti-human NK cell markers such as CD16 and CD56 could be easily established for measuring human NK level. To our best knowledge, there is no established method yet for determining the actual number of NK cells in PBL. We believe that monitoring NK level (percent and/ or the actual number in PBL) and activity is important because it could help better design and optimize preclinical and clinical trials of antibody and Icon immunotherapy, particularly in combination with NK-enhancing treatment.

\section{Concluding Remarks}

In our opinion, the impairment of NK cells is a common yet often neglected challenge in antibody immunotherapy of cancer. To bring this attention to the field and even to more general readers, we briefly reviewed the current strategies and efforts on enhancing NK activity, including infusion of cytokines, vaccines, NK cells and/or the use of dietary supplements. The latter has been more extensively reviewed by Dr. Thornthwaite and co-workers [23] and by many others, as discussed above. Furthermore, we discussed the limitations of these current strategies, identified some remaining challenges and proposed to develop immortalized effector NK lines and NK level/activity assays as common standards for future clinical trials and applications of Icon and antibody immunotherapy. Moreover, we proposed to combine these biologic agents, NK cells and/or dietary supplements with antibody or Icon immunotherapy in order to overcome the NK impairment, and ultimately, to achieve the optimal efficacy and clinical outcome of Icon and antibody for cancer immunotherapy.

\section{Acknowledgements}

The work on TF-targeted therapies by using fVII summarized in this review article was partly supported by CT DPH Biomedical Research Grant (RFP\#2009-0096), the Breast Cancer Alliance Exceptional Project Grant, the Susan Komen Award (BCTR0601204) and the Swebilius Translational Cancer Research Award from the Yale Cancer Center and partly by institutional support from the Yale Department of Obstetrics, Gynecology and Reproductive Sciences and from The Ohio State University College of Medicine.

\section{REFERENCES}

[1] R. B. Herberman, "Cancer Immunotherapy with Natural Killer Cells," Seminars in Oncology, Vol. 29, No. 3, 2002, pp. 27-30. doi:10.1053/sonc.2002.33079

[2] T. L. Whiteside, N. L. Vujanovic and R. B. Herberman, "Natural Killer Cells and Tumor Therapy," Current Topics in Microbiology and Immunology, Vol. 230, 1998, pp. 221-244. doi:10.1007/978-3-642-46859-9_13

[3] S. S. Farag, T. Fehniger, L. Ruggeri, A. Velardi and M. A. Caligiuri, "Natural Killer Cells: Biology and Application in Stem-Cell Transplantation," Cytotherapy, Vol. 4, No. 5, 2002, pp. 445-446. doi:10.1080/146532402320776134

[4] P. H. Basse, T. L. Whiteside and R. B. Herberman, "Cancer Immunotherapy with Interleukin-2-Activated Natural Killer Cells," Molecular Biotechnology, Vol. 21, No. 2, 2002, pp. 161-170. doi:10.1385/MB:21:2:161

[5] P. H. Basse, T. L. Whiteside and R. B. Herberman, "Use of Activated Natural Killer Cells for Tumor Immunotherapy in Mouse and Human," Methods in Molecular Biology, Vol. 121, 2000, pp. 81-94.

[6] L. Yan, K. Hsu and R. A. Beckman, "Antibody-Based Therapy for Solid Tumors," Cancer Journal, Vol. 14, No. 3, 2008, pp. 178-183. doi:10.1097/PPO.0b013e318172d71a

[7] Z. Hu, "Factor VII-Targeted Photodynamic Therapy for Breast Cancer and Its Therapeutic Potential for Other Solid Cancers and Leukemia, Breast Cancer-Current and Alternative Therapeutic Modalities, Esra Gunduz and Mehmet Gunduz," 2011.

http://www.intechopen.com/articles/show/title/factor-vii-t ageted-photodynamic-therapy-for-breast-cancer-and-its-th erapeutic-potential-for-other-s

[8] Z. Hu, Y. Sun and A. Garen, "Targeting Tumor Vasculature Endothelial Cells and Tumor Cells for Immunotherapy of Human Melanoma in a Mouse Xenograft Model," Proceedings of the National Academy of Sciences of United States of America, Vol. 96, No. 14, 1999, pp. 8161-8166.

[9] Z. Hu and A. Garen, "Intratumoral Injection of Adenoviral Vectors Encoding Tumor-Targeted Immunoconjugates for Cancer Immunotherapy," Proceedings of the National Academy of Sciences of United States of America, Vol. 97, No. 16, 2000, pp. 9221-9225. doi:10.1073/pnas.97.16.9221

[10] Z. Hu and A. Garen "Targeting Tissue Factor on Tumor Vascular Endothelial Cells and Tumor Cells for Immunotherapy in Mouse Models of Prostatic Cancer," Proceedings of the National Academy of Sciences of United States of America, Vol. 98, No. 21, 2001, Article ID: 12180. doi:10.1073/pnas.201420298

[11] Z. Hu and J. Li, "Natural Killer Cells Are Crucial for the Efficacy of Icon (Factor VII/Human IgG1 Fc) Immunotherapy in Human Tongue Cancer," BMC Immunology, Vol. 11, 2010, p. 49. doi:10.1186/1471-2172-11-49

[12] J. Contrino, G. Hair, D. L. Kreutzer and F. R. Rickles, "In Situ Detection of Tissue Factor in Vascular Endothelial Cells: Correlation with the Malignant Phenotype of Human Breast Disease," Nature Medicine Vol. 2, No. 2, 1996, pp. 209-215. doi:10.1038/nm0296-209 
[13] Y. Tang, P. Borgstrom, J. Maynard, J. Koziol, Z. Hu, A. Garen and A. Deisseroth, "Mapping of Angiogenic Markers for Targeting of Vectors to Tumor Vascular Endothelial Cells," Cancer Gene Therapy, Vol. 14, No. 4, 2007, pp. 346-353. doi:10.1038/sj.cgt.7701030

[14] E. Cocco, Z. Hu, C. E. Richter, S. Bellone, F. Casagrande, M. Bellone, P. Todeschini, G. Krikun, D. A. Silasi, M. Azodi, P. E. Schwartz, T. J. Rutherford, N. Buza, S. Pecorelli, C. J. Lockwood and A. D. Santin, "hI-con1, a factor VII-IgGFc Chimeric Protein Targeting Tissue Factor for Immunotherapy of Uterine Serous Papillary Carcinoma," British Journal of Cancer, Vol. 103, No. 6, 2010, pp. 812-819. doi:10.1038/sj.bjc.6605760

[15] P. S. Bora, Z. Hu, T. H. Tezel, J. H. Sohn, S. G. Kang, J. M. Cruz, N. S. Bora, A. Garen and H. J. Kaplan, "Immunotherapy for Choroidal Neovascularization in a LaserInduced Mouse Model Simulating Exudative (Wet) Macular Degeneration," Proceedings of the National Academy of Sciences of United States of America Vol. 100, No. 5, 2003, pp. 2679-2684. doi:10.1073/pnas.0438014100

[16] T. H. Tezel, E. Bodek, K. Sonmez, S. Kaliappan, H. J. Kaplan, Z. Hu and A. Garen, "Targeting Tissue Factor for Immunotherapy of Choroidal Neovascularization by Intravitreal Delivery of Factor VII-Fc Chimeric Antibody," Ocular Immunology and Inflammation, Vol. 15, No. 1, 2007, pp. 3-10. doi:10.1080/09273940601147760

[17] G. Krikun, Z. Hu, K. Osteen, K. L. Bruner-Tran, F. Schatz, H. S. Taylor, P. Toti, F. Arcuri, W. Konigsberg, A. Garen, C. J. Booth and C. J. Lockwood, "The Immunoconjugate 'Icon' Targets Aberrantly Expressed Endothelial Tissue Factor Causing Regression of Endometriosis," The American Journal of Pathology, Vol. 176, No. 2, 2010, pp. 1050-1056. doi:10.2353/ajpath.2010.090757

[18] P. Carter, L. Presta, C. M. Gorman, J. B. Ridgway, D. Henner, W. L. Wong, A. M. Rowland, C. Kotts, M. E. Carver and H. M. Shepard, "Humanization of an AntiP185HER2 Antibody for Human Cancer Therapy," Proceedings of the National Academy of Sciences of United States of America, Vol. 89, No. 10, 1992, pp. 4285- 4289. doi:10.1073/pnas.89.10.4285

[19] M. E. Reff, K. Carner, K. S. Chambers, P. C. Chinn, J. E. Leonard, R. Raab, R. A. Newman, N. Hanna and D. R. Anderson, "Depletion of B Cells in Vivo by a Chimeric Mouse Human Monoclonal Antibody to CD20," Blood, Vol. 83, No. 2, 1994, pp. 435-445.

[20] J. Kurai, H. Chikumi, K. Hashimoto, K. Yamaguchi, A. Yamasaki, T. Sako, H. Touge, H. Makino, M. Takata, M. Miyata, M. Nakamoto, N. Burioka and E. Shimizu, "Antibody-Dependent Cellular Cytotoxicity Mediated by Cetuximab against Lung Cancer Cell Lines," Clinical Cancer Research, Vol. 13, No. 5, 2007, pp. 1552-1561. doi:10.1158/1078-0432.CCR-06-1726

[21] R. Kiessling, E. Klein, H. Pross and H. Wigzell, “"Natural' Killer Cells in The Mouse. II. Cytotoxic Cells with Specificity for Mouse Moloney Leukemia Cells. Characteristics of the Killer Cell," European Journal of Immunology, Vol. 5, No. 2, 1975, pp. 117-121. doi:10.1002/eji.1830050209

[22] R. B. Herberman, M. E. Nunn, H. T. Holden and D. H. Lavrin, "Natural Cytotoxic Reactivity of Mouse Lym- phoid Cells against Syngeneic and Allogeneic Tumors. II. Characterization of Effector Cells," International Journal of Cancer, Vol. 16, No. 2, 1975, pp. 230-239. doi:10.1002/ijc.2910160205

[23] J. Thornthwaite, H. Shah, P. Shah and H. Respess, "The Natural Killer Cell: A Historical Perspective and the Use of Supplements to Enhance NKC Activity," Journal of Immune Based Therapies, Vaccines and Antimicrobials, Vol. 1, No. 3, 2012, pp. 21-51. doi:10.4236/jibtva.2012.13004

[24] R. B. Herberman, J. Djeu, H. D. Kay, J. R. Ortaldo, C. Riccardi, G. D. Bonnard, H. T. Holden, R. Fagnani, A. Santoni and P. Puccetti, "Natural Killer Cells: Characteristics and Regulation of Activity," Immunological Reviews, Vol. 44, No. 1, 1979, pp. 43-70.

doi:10.1111/j.1600-065X.1979.tb00267.x

[25] R. Kiessling, K. Wasserman, S. Horiguchi, K. Kono, J. Sjoberg, P. Pisa and M. Petersson, "Tumor-Induced Immune Dysfunction," Cancer Immunology Immunotherapy, Vol. 48, No. 7, 1999, pp. 353-362. doi: $10.1007 / \mathrm{s} 002620050586$

[26] T. Sutlu and E. Alici, "Natural Killer Cell-Based Immunotherapy in Cancer: Current Insights and Future Prospects," Journal of Internal Medicine, Vol. 266, No. 2, 2009, pp. 154-181. doi:10.1111/j.1365-2796.2009.02121.x

[27] S. P. Schantz, B. W. Brown, E. Lira, D. L. Taylor and N. Beddingfield, "Evidence for the Role of Natural Immunity in the Control of Metastatic Spread of Head and Neck Cancer," Cancer Immunology Immunotherapy, Vol. 25, No. 2, 1987, pp. 141-148. doi:10.1007/BF00199955

[28] K. Vinzenz, M. Matejka, G. Watzek, H. Porteder, N. Neuhold and M. Micksche, "Modulation of NK Activity in Regional Lymph Nodes by Preoperative Immunotherapy with OK-432 in Patients with Cancer of the Oral Cavity," Cancer Detection and Prevention, Vol. 1, 1987, pp. 463475.

[29] K. A. Varker, C. E. Terrell, M. Welt, S. Suleiman, L. Thornton, B. L. Andersen and W. E. Carson, "Impaired Natural Killer Cell Lysis in Breast Cancer Patients with High Levels of Psychological Stress Is Associated with Altered Expression of Killer Immunoglobin-Like Receptors," The Journal of Surgical Research, Vol. 139, No. 1, 2007, pp. 36-44. doi:10.1016/j.jss.2006.08.037

[30] K. Kono, A. Takahashi, F. Ichihara, H. Sugai, H. Fujii and Y. Matsumoto, "Impaired Antibody-Dependent Cellular Cytotoxicity Mediated by Herceptin in Patients with Gastric Cancer," Cancer Research, Vol. 62, No. 20, 2002, pp. 5813-5817.

[31] Y. Kawaguchi, K. Kono, K. Mimura, F. Mitsui, H. Sugai, H. Akaike and H. Fujii, "Targeting EGFR and HER-2 with Cetuximab- and Trastuzumab-Mediated Immunotherapy in Oesophageal Squamous Cell Carcinoma," British Journal of Cancer, Vol. 97, No. 4, 2007, pp. 494501. doi:10.1038/sj.bjc. 6603885

[32] Y. Kawaguchi, K. Kono, K. Mimura, H. Sugai, H. Akaike and H. Fujii, "Cetuximab Induce Antibody-Dependent Cellular Cytotoxicity against EGFR-Expressing Esophageal Squamous Cell Carcinoma," International Journal of Cancer, Vol. 120, No. 4, 2007, pp. 781-787. 
doi:10.1002/ijc. 22370

[33] M. R. Pillai, P. Balaram, T. Abraham, T. K. Padmanabhan and M. K. Nair, "Natural Cytotoxicity and Serum Blocking in Malignant Cervical Neoplasia," American Journal of Reproductive Immunology, Vol. 16, No. 4, 1988, pp. 159-162.

[34] T. L. Ratliff, R. E. McCool and W. J. Catalona, "Antibody-Dependent and Spontaneous Lympholysis in Urologic Cancer Patients," British Journal of Cancer, Vol. 39, No. 6, 1979, pp. 667-675. doi:10.1038/bjc.1979.118

[35] C. D. Platsoucas, G. Fernandes, S. L. Gupta, S. Kempin, B. Clarkson, R. A. Good and S. Gupta, "Defective Spontaneous and Antibody-Dependent Cytotoxicity Mediated by E-Rosette-Positive and E-Rosette-Negative Cells in Untreated Patients with Chronic Lymphocytic Leukemia: Augmentation by in Vitro Treatment with Interferon," The Journal of Immunology, Vol. 125, No. 3, 1980, pp. 1216-1223.

[36] H. W. Ziegler, N. E. Kay and J. M. Zarling, "Deficiency of Natural Killer Cell Activity in Patients with Chronic Lymphocytic Leukemia," International Journal of Cancer, Vol. 27, No. 3, 1981, pp. 321-327. doi:10.1002/ijc.2910270310

[37] N. E. Kay and J. M. Zarling, "Impaired Natural Killer Activity in Patients with Chronic Lymphocytic Leukemia Is Associated with a Deficiency of Azurophilic Cytoplasmic Granules in Putative NK Cells," Blood, Vol. 63, No. 2, 1984, pp. 305-309.

[38] H. Matsuzaki, T. Kagimoto, T. Oda, F. Kawano and K. Takatsuki, "Natural Killer Activity and Antibody-Dependent Cell-Mediated Cytotoxicity in Multiple Myeloma," Japanese Journal of Clinical Oncology, Vol. 15, No. 4, 1985, pp. 611-617.

[39] J. W. Albright and J. F. Albright, "Age-Associated Impairment of Murine Natural Killer Activity," Proceedings of the National Academy of Sciences of United States of America, Vol. 80, No. 20, 1983, pp. 6371-6375. doi:10.1073/pnas.80.20.6371

[40] K. Dorshkind, S. B. Pollack, M. J. Bosma and R. A. Phillips, "Natural Killer (NK) Cells Are Present in Mice with Severe Combined Immunodeficiency (Scid)," The Journal of Immunology, Vol. 134, No. 6, 1985, pp. 37983801.

[41] J. Roder and A. Duwe, "The Beige Mutation in the Mouse Selectively Impairs Natural Killer Cell Function," Nature, Vol. 278, No. 5703, 1979, pp. 451-453. doi:10.1038/278451a0

[42] J. R. MacDougall, B. A. Croy, C. Chapeau and D. A. Clark, "Demonstration of a Splenic Cytotoxic Effector Cell in Mice of Genotype SCID/SCID.BG/BG," Cellular Immunology, Vol. 130, No. 1, 1990, pp. 106-117.

[43] R. Nahta and F. J. Esteva, "HER2 Therapy: Molecular Mechanisms of Trastuzumab Resistance," Breast Cancer Research, Vol. 8, No. 6, 2006, p. 215. doi:10.1186/bcr1612

[44] S. Varchetta, N. Gibelli, B. Oliviero, E. Nardini, R. Gennari, G. Gatti, L. S. Silva, L. Villani, E. Tagliabue, S. Menard, A. Costa and F. F. Fagnoni, "Elements Related to Heterogeneity of Antibody-Dependent Cell Cytotoxicity in Patients under Trastuzumab Therapy for Primary Operable Breast Cancer Overexpressing Her2," Cancer Research, Vol. 67, No. 24, 2007, pp. 11991-11999. doi:10.1158/0008-5472.CAN-07-2068

[45] M. Ostensen and O. Forre, "Modulation of Human Natural Killer Cell Function by Cytokines and Rheumatic Disease," Scandinavian Journal of Rheumatology. Supplement, Vol. 17, No. s76, 1988, pp. 183-188. doi:10.3109/03009748809102968

[46] M. J. Brunda, "Interleukin-12," Journal of Leukocyte Biology, Vol. 55, No. 2, 1994, pp. 280-288.

[47] L. Oleksowicz and J. P. Dutcher, "A Review of the New Cytokines: IL-4, IL-6, IL-11, and IL-12,” American Journal of Therapeutics, Vol. 1, No. 2, 1994, pp. 107-115. doi:10.1097/00045391-199408000-00002

[48] M. Cheng, J. Zhang, W. Jiang, Y. Chen and Z. Tian, "Natural Killer Cell Lines in Tumor Immunotherapy," Frontiers of Medicine, Vol. 6, No. 1, 2012, pp. 56-66. doi:10.1007/s11684-012-0177-7

[49] A. S. Fauci, S. A. Rosenberg, S. A. Sherwin, C. A. Dinarello, D. L. Longo and H. C. Lane, "NIH Conference. Immunomodulators in Clinical Medicine," Annals of Internal Medicine, Vol. 106, No. 3, 1987, pp. 421-433.

[50] M. T. Lotze, M. C. Custer, E. S. Bolton, E. A. Wiebke, Y. Kawakami and S. A. Rosenberg, "Mechanisms of Immunologic Antitumor Therapy: Lessons from the Laboratory and Clinical Applications," Human Immunology, Vol. 28, No. 2, 1990, pp. 198-207. doi:10.1016/0198-8859(90)90020-P

[51] Z. K. Ballas, "Modulation of NK Cell Activity by CpG Oligodeoxynucleotides," Immunology Research, Vol. 39, No. 1-3, 2007, pp. 15-21. doi:/10.1007/s12026-007-0066-3

[52] M. H. Shah, R. A. Baiocchi, T. A. Fehniger, V. P. Khatri, M. Gould, B. Poiesz, Z. P. Bernstein and M. A. Caligiuri, "Cytokine Replacement in Patients with HIV-1 NonHodgkin's Lymphoma: The Rationale for Low-Dose Interleukin-2 Therapy," The Cancer Journal from Scientific American, Vol. 6, No. S1, 2000, pp. S45-S51.

[53] N. S. Bhave and W. E. Carson, 3rd, "Immune Modulation with Interleukin-21," Annals of the New York Academy of Sciences, Vol. 1182, 2009, pp. 39-46. doi:/10.1111/j.1749-6632.2009.05071.x

[54] J. Copier and A. Dalgleish, "Whole-Cell Vaccines: A Failure or a Success Waiting to Happen?" Current Opinion in Molecular Therapeutics, Vol. 12, No. 1, 2010, pp. 14-20.

[55] J. P. Siegel and R. K. Puri, "Interleukin-2 Toxicity," Journal of Clinical Oncology, Vol. 9, No. 4, 1991, pp. 694 704.

[56] K. Nakagawa, F. N. Miller, D. E. Sims, A. B. Lentsch, M. Miyazaki and M. J. Edwards, "Mechanisms of Interleukin-2-Induced Hepatic Toxicity," Cancer Research, Vol. 56, No. 3, 1996, pp. 507-510.

[57] R. Passalacqua, C. Buzio, S. Buti, C. Porta, R. Labianca, D. Pezzuolo, R. Camisa, R. Sabbatini, L. Benecchi, C. Messina, R. Cengarle, A. Vaglio, M. Dalla Chiesa, G. Tomasello and C. Caminiti, "Phase III, Randomised, Multicentre Trial of Maintenance Immunotherapy with Low- 
Dose Interleukin-2 and Interferon-Alpha for Metastatic Renal Cell Cancer," Cancer Immunology, Immunotherapy, Vol. 59, No. 4, 2010, pp. 553-561. doi:/10.1007/s00262-009-0773-9

[58] J. Lister, W. B. Rybka, A. D. Donnenberg, M. deMagalhaes-Silverman, S. M. Pincus, E. J. Bloom, E. M. Elder, E. D. Ball and T. L. Whiteside, "Autologous Peripheral Blood Stem Cell Transplantation and Adoptive Immunotherapy with Activated Natural Killer Cells in the Immediate Posttransplant Period," Clinical Cancer Research, Vol. 1, No. 6, 1995, pp. 607-614.

[59] M. deMagalhaes-Silverman, A. Donnenberg, B. Lembersky, E. Elder, J. Lister, W. Rybka, T. Whiteside and E. Ball, "Posttransplant Adoptive Immunotherapy with Activated Natural Killer Cells in Patients with Metastatic Breast Cancer," Journal of Immunotherapy, Vol. 23, No. 1, 2000, pp. 154-160. doi:/10.1097/00002371-200001000-00018

[60] V. Bachanova, L. J. Burns, D. H. McKenna, J. Curtsinger, A. Panoskaltsis-Mortari, B. R. Lindgren, S. Cooley, D. Weisdorf and J. S. Miller, "Allogeneic Natural Killer Cells for Refractory Lymphoma," Cancer Immunology, Immunotherapy, Vol. 59, No. 11, 2010, pp. 1739-1744. doi:/10.1007/s00262-010-0896-Z

[61] E. Ishikawa, K. Tsuboi, K. Saijo, H. Harada, S. Takano, T. Nose and T. Ohno, "Autologous Natural Killer Cell Therapy for Human Recurrent Malignant Glioma," Anticancer Research, Vol. 24, No. 3b, 2004, pp. 1861-1871.

[62] M. R. Parkhurst, J. P. Riley, M. E. Dudley and S. A. Rosenberg, "Adoptive Transfer of Autologous Natural Killer Cells Leads to High Levels of Circulating Natural Killer Cells but Does Not Mediate Tumor Regression," Clinical Cancer Research, Vol. 17, No. 19, 2011, pp. 6287-6297.doi:/10.1158/1078-0432.CCR-11-1347

[63] D. H. McKenna Jr., D. Sumstad, N. Bostrom, D. M. Kadidlo, S. Fautsch, S. McNearney, R. Dewaard, P. B. McGlave, D. J. Weisdorf, J. E. Wagner, J. McCullough and J. S. Miller, "Good Manufacturing Practices Production of Natural Killer Cells for Immunotherapy: A Six-Year Single-Institution Experience," Transfusion, Vol. 47, No. 3, 2007, pp. 520-528. doi:/10.1111/j.1537-2995.2006.01145.x

[64] Y. P. Tang, P. G. Li, M. Kondo, H. P. Ji, Y. Kou and B. $\mathrm{Ou}$, "Effect of a Mangosteen Dietary Supplement on Human Immune Function: A Randomized, Double-Blind, Placebo-Controlled Trial," Journal of Medicinal Food, Vol. 12, No. 4, 2009, pp. 755-763. doi:/10.1089/jmf.2008.0204

[65] B. G. Jung, N. T. Toan, S. J. Cho, J. H. Ko, Y. K. Jung and B. J. Lee, "Dietary Aluminosilicate Supplement Enhances Immune Activity in Mice and Reinforces Clearance of Porcine Circovirus Type 2 in Experimentally Infected Pigs," Veterinary Microbiology, Vol. 143, No. 2-4, 2010, pp. 117-125. doi:/10.1016/j.vetmic.2009.11.009

[66] Y. Li, T. Zhang, H. Korkaya, S. Liu, H. F. Lee, B. Newman, Y. Yu, S. G. Clouthier, S. J. Schwartz, M. S. Wicha and D. Sun, "Sulforaphane, a Dietary Component of Broccoli/Broccoli Sprouts, Inhibits Breast Cancer Stem Cells," Clinical Cancer Research, Vol. 16, No. 9, 2010, pp. 2580-2590. doi:/10.1158/1078-0432.CCR-09-2937
[67] K. R. Landis-Piwowar, C. Huo, D. Chen, V. Milacic, G. Shi, T. H. Chan and Q. P. Dou, "A Novel Prodrug of the Green Tea Polyphenol (-)-Epigallocatechin-3-Gallate as a Potential Anticancer Agent," Cancer Research, Vol. 67, No. 9, 2007, pp. 4303-4310. doi:/10.1158/0008-5472.CAN-06-4699

[68] A. P. Sommer, D. Zhu and T. Scharnweber, "Extraordinary Anticancer Effect of Green Tea and Red Light," Photomedicine and Laser Surgery, Vol. 28, No. 3, 2010, pp. 429-430. doi:/10.1089/pho.2009.2706

[69] D. M. Morre and D. J. Morre, "Anticancer Activity of Grape and Grape Skin Extracts Alone and Combined with Green Tea Infusions," Cancer Letters, Vol. 238, No. 2, 2006, pp. 202-209. doi:/10.1016/j.canlet.2005.07.011

[70] T. Pannellini, M. Iezzi, M. Liberatore, F. Sabatini, S. Iacobelli, C. Rossi, S. Alberti, C. Di Ilio, P. Vitaglione, V. Fogliano and M. Piantelli, "A Dietary Tomato Supplement Prevents Prostate Cancer in TRAMP Mice," Cancer Prevention Research, Vol. 3, No. 10, 2010, pp. 12841291. doi:/10.1158/1940-6207.CAPR-09-0237

[71] R. Cooper, D. J. Morre and D. M. Morre, "Medicinal Benefits of Green Tea: Part II. Review of Anticancer Properties," The Journal of Alternative and Complementary Medicine, Vol. 11, No. 4, 2005, pp. 639-652. doi:/10.1089/acm.2005.11.639

[72] L. M. Dong, A. R. Kristal, U. Peters, J. M. Schenk, C. A. Sanchez, P. S. Rabinovitch, P. L. Blount, R. D. Odze, K. Ayub, B. J. Reid and T. L. Vaughan, "Dietary Supplement Use and Risk of Neoplastic Progression in Esophageal Adenocarcinoma: A Prospective Study," Nutrition and Cancer, Vol. 60, No. 1, 2008, pp. 39-48. doi:/10.1080/01635580701586762

[73] M. F. Miller, K. M. Bellizzi, M. Sufian, A. H. Ambs, M. S. Goldstein and R. Ballard-Barbash, "Dietary Supplement Use in Individuals Living with Cancer and Other Chronic Conditions: A Population-Based Study," Journal of the American Dietetic Association, Vol. 108, No. 3, 2008, pp. 483-494. doi:/10.1016/i.jada.2007.12.005

[74] P. Miller, W. Demark-Wahnefried, D. C. Snyder, R. Sloane, M. C. Morey, H. Cohen, S. Kranz, D. C. Mitchell and T. J. Hartman, "Dietary Supplement Use among Elderly, Long-Term Cancer Survivors," Journal of Cancer Survivorship, Vol. 2, No. 3, 2008, pp. 138-148. doi:/10.1007/s11764-008-0060-3

[75] C. L. Van Patten, J. G. de Boer and E. S. Tomlinson Guns, "Diet and Dietary Supplement Intervention Trials for the Prevention of Prostate Cancer Recurrence: A Review of the Randomized Controlled Trial Evidence," Journal of Urology, Vol. 180, No. 6, 2008, pp. 2314-2321.

[76] P. E. Miller, J. J. Vasey, P. F. Short and T. J. Hartman, "Dietary Supplement Use in Adult Cancer Survivors," Oncology Nursing Forum, Vol. 36, No. 1, 2009, pp. 6168. doi:/10.1188/09.ONF.61-68

[77] M. L. Neuhouser, M. J. Barnett, A. R. Kristal, C. B. Ambrosone, I. B. King, M. Thornquist and G. G. Goodman, "Dietary Supplement Use and Prostate Cancer Risk in the Carotene and Retinol Efficacy Trial," Cancer Epidemiology, Biomarkers \& Prevention, Vol. 18, No. 8, 2009, pp. 2202-2206. doi:/10.1158/1055-9965.EPI-09-0013 
[78] M. A. Moyad and L. H. Klotz, "Statin Clinical Trial (REALITY) for Prostate Cancer: An over 15-Year Wait Is Finally over Thanks to a Dietary Supplement," Urologic Clinics of North America, Vol. 38, No. 3, 2011, pp. 325-331. doi:/10.1016/j.ucl.2011.05.002

[79] J. Saquib, C. L. Rock, L. Natarajan, N. Saquib, V. A. Newman, R. E. Patterson, C. A. Thomson, W. K. Al-Delaimy and J. P. Pierce, "Dietary Intake, Supplement Use, and Survival among Women Diagnosed with Early-Stage Breast Cancer," Nutrition and Cancer, Vol. 63, No. 3, 2011, pp. 327-333. doi:/10.1080/01635581.2011.535957

[80] A. Westerlund, G. Steineck, K. Balter, P. Stattin, H. Gronberg and M. Hedelin, "Dietary Supplement Use Patterns in Men with Prostate Cancer: The Cancer Prostate Sweden Study," Annals of Oncology, Vol. 22, No. 4, 2011, pp. 967-972. doi:/10.1093/annonc/mdq456

[81] P. Gardiner, D. N. Sarma, T. Low Dog, M. L. Barrett, M. L. Chavez, R. Ko, G. B. Mahady, R. J. Marles, L. S. Pellicore and G. I. Giancaspro, "The State of Dietary Supplement Adverse Event Reporting in the United States," Pharmacoepidemiol Drug Safety, Vol. 17, No. 10, 2008, pp. 962-970. doi:/10.1002/pds.1627

[82] M. L. Hardy, "Dietary Supplement Use in Cancer Care: Help or Harm," Hematology/Oncology Clinics of North America, Vol. 22, No. 4, 2008, pp. 581-617. doi:/10.1016/j.hoc.2008.04.012

[83] V. J. Navarro, "Herbal and Dietary Supplement Hepatotoxicity," Seminars in Liver Disease, Vol. 29, No. 4, 2009 pp. 373-382. doi:/10.1055/s-0029-1240006

[84] R. K. Miller, C. Celestino, G. I. Giancaspro and R. L. Williams, "FDA's Dietary Supplement Cgmps: Standards without Standardization," Food and Drug, Law Journal, Vol. 63, No. 4, 2008, pp. 929-942. doi:/10.1038/287047a0

[85] G. Dennert, "Cloned Lines of Natural Killer Cells," $\mathrm{Na}$ ture, Vol. 287, No. 5777, 1980, pp. 47-49.

[86] M. Manoussaka, A. Georgiou, B. Rossiter, S. Shrestha, J. A. Toomey, P. V. Sivakumar, M. Bennett, V. Kumar and C. G. Brooks, "Phenotypic and Functional Characterization of Long-Lived NK Cell Lines of Different Maturational Status Obtained from Mouse Fetal Liver," The Journal of Immunology, Vol. 158, No. 1, 1997, pp. 112119.

[87] F. M. Karlhofer, M. M. Orihuela and W. M. Yokoyama, "Ly-49-Independent Natural Killer (NK) Cell Specificity
Revealed by NK Cell Clones Derived from P53-Deficient Mice," The Journal of Experimental Medicine, Vol. 181, No. 5, 1995, pp. 1785-1795. doi:/10.1084/jem.181.5.1785

[88] Q. Vos, J. R. Ortaldo, M. Conan-Cibotti, M. D. Vos, H. A. Young, S. K. Anderson, K. Witherspoon, I. Prager, C. M. Snapper and J. J. Mond, "Phenotypic and Functional Characterization of a Panel of Cytotoxic Murine NK Cell Clones That Are Heterogeneous in Their Enhancement of Ig Secretion in Vitro," International Immunology, Vol. 10, No. 8, 1998, pp. 1093-1101. doi:/10.1093/intimm/10.8.1093

[89] S. Iizuka, T. Kaifu, A. Nakamura, M. Obinata and T. Takai, "Establishment and Functional Characterization of Novel Natural Killer Cell Lines Derived from a Temperature-Sensitive SV40 Large T Antigen Transgenic Mouse," The Journal of Biochemistry, Vol. 140, No. 2, 2006, pp. 255-265. doi:/10.1093/jb/mvj153

[90] Y. Isobe, K. Sugimoto, L. Yang, K. Tamayose, M. Egashira, T. Kaneko, K. Takada and K. Oshimi, "EpsteinBarr Virus Infection of Human Natural Killer Cell Lines and Peripheral Blood Natural Killer Cells," Cancer Research, Vol. 64, No. 6, 2004, pp. 2167-2174. doi:/10.1158/0008-5472.CAN-03-1562

[91] J. H. Gong, G. Maki and H. G. Klingemann, "Characterization of a Human Cell Line (NK-92) with Phenotypical and Functional Characteristics of Activated Natural Killer Cells," Leukemia, Vol. 8, No. 4, 1994, pp. 652-658.

[92] Y. K. Tam, G. Maki, B. Miyagawa, B. Hennemann, T. Tonn and H. G. Klingemann, "Characterization of Genetically Altered, Interleukin 2-Independent Natural Killer Cell Lines Suitable for Adoptive Cellular Immunotherapy," Human Gene Therapy, Vol. 10, No. 8, 1999, pp. 1359-1373. doi:/10.1089/10430349950018030

[93] J. W. Bruning, M. J. Kardol, R. Arentzen, A. Naipal and J. J. van der Poel, "Carboxyfluorescein Fluorochromasis Assays for Cell-Mediated Lympholysis (CML) and Antibody-Dependent Cellular Cytotoxicity (ADCC): A Nonradioactive Technique," Transplantation Proceedings, Vol. 11, No. 4, 1979, pp. 1961-1963.

[94] H. Arase, T. Saito, J. H. Phillips and L. L. Lanier, "Cutting Edge: The Mouse NK Cell-Associated Antigen Recognized by DX5 Monoclonal Antibody Is CD49b (Alpha 2 Integrin, Very Late Antigen-2)," The Journal of Immunology, Vol. 167, No. 3, 2001, pp. 1141-1144. 